\title{
An Improved Method of Arachidonic Acid Production by Mortierella alpina
}

\author{
Nagao Totani*, Akira WATANABE, and Kenkichi OBA \\ Biological Science Laboratory, Lion Corporation, (202 Tajima Odawara-shi $\mathbf{T}^{256}$ )
}

\begin{abstract}
Highly unsaturated fatty acids such as $r$-linolenic and eicosapentaenoic acids are now synthesized in large quantities by microorganisms but production methods of arachidonic acid are still inadequate due to its low yield for each type of medium used. To obtain lipids containing arachidonic acid at high efficiency, a detailed study was made of the conditions for incubating Mortierella alpina on potato paste-dextrose medium, addition of trace metals, thickness of the medium layer and $\mathrm{pH} . \mathrm{My}=$ celium and pellicle were found to grow on a medium, $2 \mathrm{~mm}$ thick, containing $6 \%$ dextrose and $\mathrm{CaCl}_{2} \cdot 2 \mathrm{H}_{2} \mathrm{O} 750 \mathrm{mg} / \mathrm{kg}$ medium at $20^{\circ} \mathrm{C}$ for $20 \mathrm{~d}$. Fatty acid analysis of the lipids extracted from the dried cell indicated the yield of arachidonic acid to be $13.1 \mathrm{~g} / \mathrm{kg}$ medium.
\end{abstract}

\section{Introduction}

Gamma-linolenic acid is now available in a big amount by the profound studies by Suzuki et al. ${ }^{1)}$ followed by industrial cooperation. The biochemical synthesis of the acid could reduce the price about a half regardless of climate conditions and provide uniform quality of the product. Icosapentaenoic acid is also ob= tainable by cultivation of Chlorella which is a new species fused between ones living in sea and fresh waters ${ }^{2), 3)}$. Toyo Jozo ${ }^{4)}$, Japan pro= vides arachidonic acid obtained from lipids of Euglena gracilis grown in the dark. However, it should seem that the method is not success = ful enough to expel the conventional producs tion method because of the low yield.

The authors reported ${ }^{5), 6)}$ that Mortierella alpina was a potential fungus for the produc= tion of arachidonic acid and that the fungus grew substantially at $20^{\circ} \mathrm{C}$ for $20 \mathrm{~d}$ on a solid medium comprising potato paste and dextrose; methyl esters derived from the ex= tracted lipids contained $56.6 \%$ of arachidonic acid which yield was $11.8 \mathrm{~g} / \mathrm{kg}$ medium. This yield was more than 20 times higher than that of Toyo Jozo mentioned above and the content of the acid was desirably so high that puri= fication should be quite easy. In the present paper detailed examination was made on the incubation conditions to get better yield of arachidonic acid per amount of potato.

\begin{abstract}
Experimental $^{7) \sim 10)}$
Preparation of potato paste-dextrose medium

Washed potatoes were peeled and cut into $1 \mathrm{~cm}$ cubes. Six hundred grams of potato cubes were boiled with $400 \mathrm{~mL}$ of distilled water for $20 \mathrm{~min}$ and passed through $0.5 \mathrm{~mm}$ $\times 0.5 \mathrm{~mm}$ mesh with a spatula to make potato paste where remaining water was mixed with the paste. The paste was added distilled water to make $1,000 \mathrm{~g}$ followed by good mixing and autoclaving for $15 \mathrm{~min}$. Before cooled to room temperature the paste was mixed with sterilized dextrose solution diluted in the least amount of water and poured equally into sterilized dishes of $80 \mathrm{~mm}$ in diameter, flattened by a vibrator, then allowed to stand at room temperature for an hour.
\end{abstract}

\section{Incubation}

Mortierella alpina IFO 8568 purchased from Institute for Fermentation Osaka, Japan was used throughout the present experiment. Se= veral days after inoculation of the fungus white mycelia and pellicle covered the whole surface of the medium. Incubation was kept at $20^{\circ} \mathrm{C}$ for $20 \mathrm{~d}$; these condition were settled by the result shown in another paper ${ }^{6)}$.

\section{Fatty acid analysis}

Mycelium and pellicle grown were harvests ed, dried in a desiccator, and ground in a mortar with pestle using chloroform/methanol 
$2: 1 \mathrm{vol} / \mathrm{vol}$. Lipids were extracted further with the same solvent mixture and intereste= rified with sodium methoxide. Colorless clear methyl esters, thus obtained, were analyzed by $\mathrm{DEGS} 15 \%$ column at $190^{\circ} \mathrm{C}$ contained in a Hitachi $663-50$ gaschromatograph fitted with a flame inonization detector.

\section{Concentration of dextrose}

Relation between yield of arachidonic acid and dextrose concentration in the potato paste medium was examined using $4 \sim 15 \%$ of $\mathrm{dex}=$ trose (Fig. -1).

\section{Effect of $\mathrm{Ca}^{2+}$ addition}

In order to improve yield of arachidonic acid $\mathrm{CaCl}_{2} \cdot 2 \mathrm{H}_{2} \mathrm{O}$ and sodium acetate ${ }^{11)}$ were added respectively to the potato paste medium containing $6 \%$ of dextrose (Table-1). Thick $=$ ness of the medium layer used was $2 \mathrm{~mm}$ by the reason mentioned later.

\section{Thickness of the medium layer}

Efficiency of the plates was checked in terms of thickness; $2 \mathrm{~mm}, 4 \mathrm{~mm}$, and $6 \mathrm{~mm}$ which corresponded respectively to $10 \mathrm{~g}, 20 \mathrm{~g}$, and $30 \mathrm{~g}$ of the potato paste medium containing $6 \%$ of dextrose in a dish of $80 \mathrm{~mm}$ in diameter. Thickness of $2 \mathrm{~mm}$ was the thinnest layer possible (Fig. -2).

\section{pH}

Conventional potato extract-dextrose broth ${ }^{6)}$ made from $100 \mathrm{~g}$ of potato and $20 \mathrm{~g}$ of dextrose in a litre broth was employed to presume optimum $\mathrm{pH}$ for the arachidonic acid producs tion on the potato paste-dextrose medium. After inoculation of the fungus into the $50 \mathrm{~mL}$ media at $\mathrm{pH}$ between 4. $0 \sim 8.0$ each contained in a $500 \mathrm{~mL}$ Sakaguchi-flask incubation was kept at $20^{\circ} \mathrm{C}$ for $10 \mathrm{~d}$ under shaking (Fig.-3).

\section{Result and Discussion}

The fungal growth and yield of arachidonic acid showed optimum dextrose concentration at $9 \%$. It seems that more than $10 \%$ of dextrose inhibited the growth intensively and at $15 \%$ the fungus could hardly grow. Aras chidonic acid content in the total fatty acids was constant up to $6 \%$ but it decreased grad= ually because of the inhibition.

Preliminary incubation at $20^{\circ} \mathrm{C}$ for $20 \mathrm{~d}$ using a broth ${ }^{6)}$ comprising extract from $600 \mathrm{~g}$ potato and $6 \%$ dextrose showed that the fungus

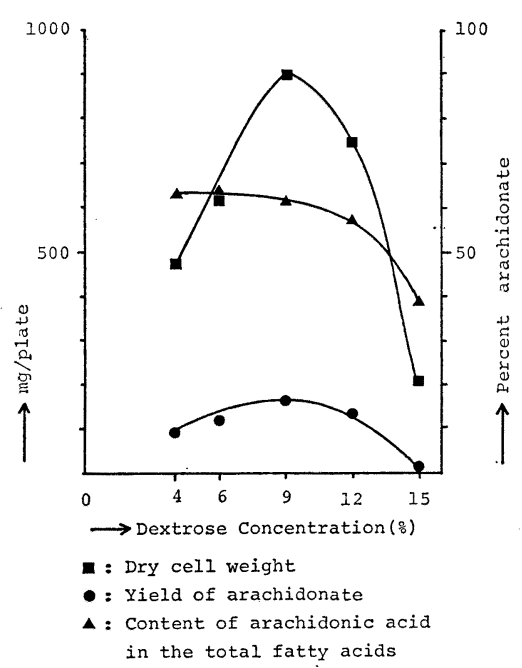

Fig.-1 Relation between dextrose concen= tration in the potato paste medium and production of arachidonic acid.

consumed dextrose at the rate of $4 \mathrm{~g} / \mathrm{d}$ since two days after inoculation. If the result could be applied to the case of the potato pastedextrose medium $72 \mathrm{~g}$ of dextrose would have been consumed after $20 \mathrm{~d}$. Then the optimum dextrose concentration, $9 \%$ was acceptable al= though content of arachidonic acid in the total fatty acids tends to decrease under too nutric tious conditions and vice versa.

Table-1 Effect of $\mathrm{Ca}^{2+}$ added in the potato paste-dextrose medium on the growth of Mortierella alpina IFO 8568.

\begin{tabular}{r|l|c|c|l}
\hline $\begin{array}{l}\mathrm{CaCl}_{2} \cdot \\
2 \mathrm{H}_{2} \mathrm{O} \\
\text { added } \\
\mathrm{mg} / \mathrm{kg} \\
\text { medium }\end{array}$ & $\begin{array}{l}\mathrm{DCW} \\
\mathrm{g} / \mathrm{kg}\end{array}$ & $\begin{array}{l}\mathrm{MA}^{\mathrm{b}} \\
\text { content } \\
\text { in the } \\
\text { methyl } \\
\text { esters } \\
(\%)\end{array}$ & $\begin{array}{l}\text { MA con= } \\
\text { tent per } \\
\mathrm{DCW}\end{array}$ & $\begin{array}{l}\text { MA yield } \\
\text { per the } \\
\text { medium }\end{array}$ \\
\hline 375 & 88.2 & 47.5 & 13.6 & $\begin{array}{l}\text { (g/kg } \\
\text { medium) }\end{array}$ \\
750 & 95.6 & 49.2 & 13.7 & 12.0 \\
1500 & 81.1 & 47.8 & 12.2 & 9.9 \\
0 & 82.4 & 46.9 & 12.5 & 10.3 \\
\hline
\end{tabular}

${ }^{\mathrm{a}} \mathrm{DCW}=$ dry cell weight, ${ }^{\mathrm{b}} \mathrm{MA}=$ methyl arachidonate

There was a tendency that calcium chloride made content of arachidonic acid in the total fatty acids higher and also the cell body slightly stiff. Sodium acetate which is reported to be one of the substances activating the metabolism in the fatty acid synthesis in the cell ${ }^{11)}$ helped increase the yield of neither arachidonic acid nor total fatty acids. 
The thickness of medium layer, $2 \mathrm{~mm}$, was the most efficient on the base of potato used. Arachidonic acid content in the total fatty acids was remarkably high in the fungus grown on a thin layer because of high con= sumption of nutrition by the fungus. The fungus can probably absorb most nutrition in the medium from down to $4 \mathrm{~mm}$ of depth although cost of the medium used would not be a decisive factor for the production of arachidonic acid. Consequently it is important how to let the fungus assimilate as much nutrition in the medium as possible, that is, the bigger area with certain amount of me= dium produces more arachidonic acid. How $=$ ever, thin plates have to be taken for the incubation under the good control of humidity during the fungal growth.

The optimum $\mathrm{pH}$, at which the highest ara chidonic acid content in the total fatty acids was observed, was shown between $5.0 \sim 6.0$ although dry cell weights and yields of total methyl esters were almost constant irrespective of the initial $\mathrm{pH}$ in the range of $4.0 \sim 8.0$. The final $\mathrm{pH}$ after $10 \mathrm{~d}$ of incubation was between $6.6 \sim 7.0$. This result indicated that the fungus was not so sensitive towards $\mathrm{pH}$ between $4.0 \sim 8.0$. Conveniently potato pastedextrose medium prepared as mentioned above

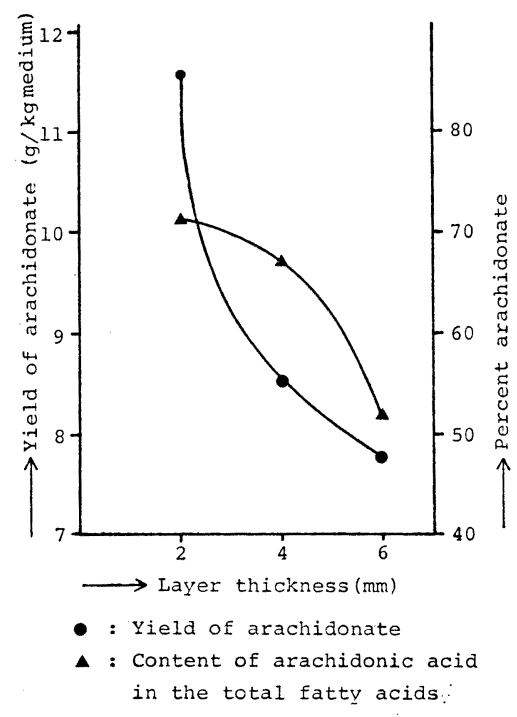

Fig.-2 Influence of medium layer thickness on the yield of arachidonate.

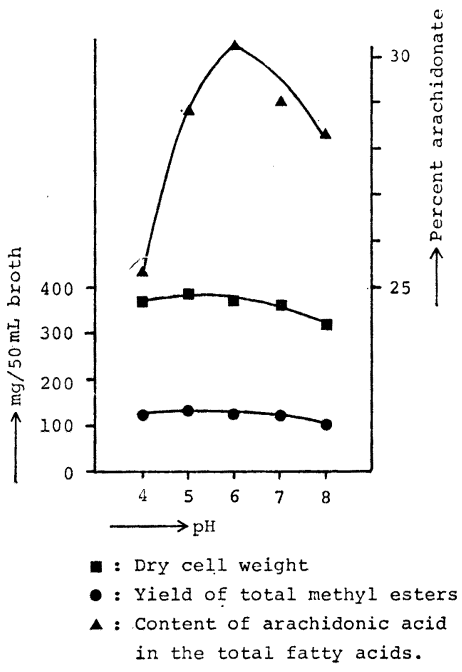

Fig.-3 Influence of intial $\mathrm{pH}$ of the potato dextrose medium on the growth of Mortierella alpina IFO 8568.

had $\mathrm{pH}$ around 5.6.

Consequntly the potato paste-dextrose medi= um, $2 \mathrm{~mm}$ thick containing $6 \%$ dextrose (and $\mathrm{CaCl}_{2} \cdot 2 \mathrm{H}_{2} \mathrm{O}, 750 \mathrm{mg} / \mathrm{kg}$ medium) was employed for the practical use considering possibility of loosing water from the medium under dry environment which brings increase of dextrose concentration in the medium.

The lipids and methyl esters obtained from the fungus had slightly dark color when it was cultivated on the medium containing pigments which occurred during autoclaving.

As general, the incubation conditions rela= tively poor or insufficient for the fungal growth increase the content of arachidonic acid in the total fatty acids.

The neutral glycerides obtained have special character, that is, arachidonic acid is attached not only to the beta position of the glycerol backbone but also the alpha positions. Among these, there are tri-, $\mathrm{di}^{-}$, and mono-arachidonyl glycerol where rests of glycerol backbone were occupied mostly with palmitic, stearic, oleic, linoleic, or $\gamma$-linolenic acid.

\section{Conclusion}

Mortierella alpina IFO 8568 was inoculated on $2 \mathrm{~mm}$ thick layer comprising $1,000 \mathrm{~g}$ paste made of $600 \mathrm{~g}$ potato boiled in water, $60 \mathrm{~g}$ 
dextrose, and $750 \mathrm{mg} \mathrm{CaCl}_{2} \cdot 2 \mathrm{H}_{2} \mathrm{O}$. Incubation was kept at $20^{\circ} \mathrm{C}$ for $20 \mathrm{~d}$ followed by colo lection of the mycelium and pellicle. Lipids were extracted from the dried and ground cell and subjected to fatty acid analysis after interesterification. The yield of arachidonic acid accounted for $13.1 \mathrm{~g} / \mathrm{kg}$ medium which corresponded to $49.2 \%$ of the total fatty acids.

(Received Dec. 26, 1986)

\section{References}

1) O. Suzuki, T. Yokochi, and T. Yamashina, Yukagaku, 30, 863 (1981); ibid., 31, 921 (1982). O. Suzuki, T. Yokochi, and S. Na= kasato, Japanese Patent Notice, 58-22199, Japanese Patent Publication, 59-130191. O. Suzuki and T. Yokochi, Japanese Patent Publication 59-205979.

2) Nikkei Industrial Newspaper, 1985.7.9.

3) Nikkan Industrial Newspaper, 1985.10.17.

4) Nikkei Industrial Newspaper, 1986.2.5.

5) N. Totani and K. Oba, Lipids, submitted.

6) N. Totani and K. Oba, J. Am. Oil Chem. Soc., submitted.

7) N. Totani, K. Suzaki, and T. Kudo, Japanese Patent Application, 60-218558 (1985), 61-73450 (1986), 61-211267 (1986).

8) N. Totani, K. Suzaki, and T. Kudo, Japanese
Patent Application, 61-212168 (1986).

9) N. Totani, K. Suzaki, and T. Kudo, European Patent Application, 86113088.8 (1986).

10) N. Totani, K. Suzaki, and T. Kudo, American Patent Application, 910,605.

11) O. Suzuki, Fermentation and Industry, 43, 1024 (1985).

モルティエレラ・アルピナによる

アラキドン酸の改良生産法

$$
\begin{aligned}
& \text { 戸谷永生・渡辺 晃・大場健吉 } \\
& \text { ライオン株式会社生物科学研究所 } \\
& \text { (†256 小田原市田島 202) }
\end{aligned}
$$

rーリノレン酸やイコサペンタエン酸のような高度不飽 和脂肪酸は, 現在, 微生物を用いて大量に合成される が,アラキドン酸の生産法は低収率のため,まだ検討の 余地があると考えられる。アラキドン酸含有脂質を効率 よく得るために, Mortierella alpina をポテトペースト ・デキストロース培地上で培養する際の詳細な条件を, 培地中のデキストロース濃度, 微量金属の添加, 培地層 厚, $\mathrm{pH}$ の点から検討した。その結果, 菌糸と菌床を 6 $\%$ のデキストロースと $\mathrm{CaCl}_{2} \cdot 2 \mathrm{H}_{2} \mathrm{O} 750 \mathrm{mg} / \mathrm{kg}$ 培地 を含む厚さ $2 \mathrm{~mm}$ の培地上で, $20^{\circ} \mathrm{C} 20 \mathrm{~d}$ 間培養する 条件を選定した。乾燥菌体よりそれらの脂質を抽出し脂 肪酸分析したところ, アラキドン酸の収量は $13.1 \mathrm{~g} / \mathrm{kg}$ 培地となった。

\section{国際油脂情報}

\section{㘧新刊図}

"Topics in Lipid Research-From Structural Elucidation to Biological Function", R.A. Klein and B. Schmitz, editors; Royal Society of Chemistry, London, 1986, 348 pp, 価格 65 ドル, 申込先 : Royal Society of Chemistry, Burlington House, Piccadilly, London WIV OBN, United Kingdom

\section{支新刊図亲}

"Proceeding of 13th Scandinavian Symposium on Lipids", R. Marcuse, editor; Lipidforum, Göte= borg, Sweden, 1986, 229 pp, 価格 20 ドル “Proceeding of Lipid Oxidation: Biological and Food Chemical Aspects, R. Marcuse, editor: Scandinavian Forum for Lipid Research and Training, Göte= borg, Sweden, 1986, 206 pp, 価格 33 ドル, 申込先 : Lipidforum, c/o SIK, Box 5401, S-402 29 Göteborg, Sweden

〔INFO 4 月号 (1987) 吉富 和彦〕 